\title{
The Contribution of Pedagogical Competence and Motivation to Get Achievement of the Teachers of Physical Education, Health, and Sports
}

\author{
Fajriah, Maruful Kahri, Syamsul Arifin \\ Department of Sport Education and Health \\ Lambung Mangkurat University \\ Banjarmasin, Indonesia \\ fajriah_aj@yahoo.com
}

\begin{abstract}
The objectives of this study are to describe the contribution of pedagogical competence and motivation towards the working performance of the teachers of physical education, health, and sports in the Elementary Schools in The District of Kusan Hilir, The Regency of Tanah Bumbu. The research method used is ex post facto. The population of the study is the whole number of teachers of physical education, health, and sports in the Elementary Schools in The District of Kusan Hilir, The Regency of Tanah Bumbu. The sample consisting of 40 teachers and taken by using sampling satisfaction. The result of the study shows that 1) there is a significant contribution of pedagogical competence to the performance of teachers; 2 ) there is a significant contribution of motivation to get the achievement on teachers performance; 3 ) there is a significant contribution of pedagogical competence and motivation to get the achievement of teacher performance
\end{abstract}

Keywords: competency pedagogy, motivation achievement, working performance.

\section{INTRODUCTION}

Education is the most important tool in the development of human resources and the nation's character [1]. The dignity of a nation is largely determined by the quality of its education. In the context of the Indonesian nation, improving the quality of education is a development target in the field of national education and an integral part of efforts to improve the quality of Indonesian people as a whole.

Considering the important role of education for people's lives, in the decade of the current era of development, the government has always tried to improve the quality of education, including improving the quality of teacher productivity. The hope is that education in Indonesia rises from adversity and is at the forefront of nation-building. This form of attention is specifically reflected in government policies, among others in the form of fulfilling infrastructure facilities, legislation, increasing the applicable education budget to advance education.

This is an effort based on awareness to realize the mandate of the constitution placed on the founding father of this country, namely in Article 31 paragraph (2) of the 1945 Constitution which requires that: "Every citizen is obliged to follow basic education and the government is obliged to finance it. ". Then in Article 31 paragraph (3) which states, that: "The government is endeavoring and organizing a national education system, which enhances faith and piety and noble character in the context of the intellectual life of the nation, which is regulated by law" [2].

The quality of education is expected to improve by increasing references and increasing pedagogical competence from the Physical Education Teacher to manage the teaching and learning process which includes the ability to understand students, design programs, organize programs, carry out evaluation of teaching and learning outcomes, and be able to develop students to actualize various potentials they have. But there are differences in achievement motivation that occur between teacher performance to improve the quality of education. Furthermore, another obstacle that occurs is that not all schools have adequate facilities and infrastructure also performance has not been carried out optimally.

The teacher is one component that is very important for the implementation of the education process [3]. The existence of the teacher as the facilitator organizes student learning processes [4]. Therefore, its presence and professionalism greatly contribute to realizing national education programs. The teacher is very important for the success of learning in school. The teacher has a duty as an educator, instructor, and trainer. Educating means continuing and developing life values. While teaching means continuing and developing science, knowledge, and technology. Therefore teachers are required to have more maximum competence, especially pedagogical competencies. Based on the Minister of National Education Regulation No. 16 of 2007, a teacher must have 10 pedagogical competencies, namely the ability to manage the Teaching and Learning Process, which is as follows: 1) Mastering student's characteristics from physical, moral, social, cultural, emotional and intellectual aspects; 2) Mastering learning theory and principles of educational learning; 3) Able to develop curriculum related to the development field that lights up; 4) Carry out educational development activities; 5) Utilizing information and communication technology to carry out educational development activities; 6) Facilitating the development of students' potential to actualize the various potentials they have; 7) Communicate effectively, empathically, and politely with students; 8) Assess and evaluate learning processes and results; 9) Utilizing the results of assessment and evaluation for learning purposes; 10) Take reflective actions to improve the quality of learning. 
Based on the results of observations and existing educational data, it draws that the performance of Physical Education and Sports teachers is still not optimal. Likewise, the results of the implementation of the Teacher Competency Test still showed suboptimal results. Because there are still some Modules with the status of 'Not Fulfilling', especially module $\mathrm{C}$, module $\mathrm{D}$, module $\mathrm{E}$, module $\mathrm{F}$, module I, and module J. It can be assumed that the individual factor of the teacher's competence is still low.

From the data of twenty-six people who took the Teacher Competency Test activities with an average passing standard set of 5.50, there were only a few people who exceeded or met these averages. While the rest obtained below average results. The Teacher Competency Test activity itself uses 10 Module Standards and only a few people from each module standards get a score (report card) as 'Not Fulfilling' so that they get a 'Red' report card. This shows that the performance, achievement, and pedagogical competence of the Physical and Sports Physical Education Teachers, especially in the Kusan Hilir District still need to be improved and improved, especially in increasing the knowledge and ability to use IT. This matter is also caused by several factors that originate from 2 (two) factors, namely: (1) internal factors of the teacher itself and (2) external factors that originate from outside.

The condition of physical education and sports teachers in several elementary schools in Kusan Hilir Subdistrict, Tanah Bumbu District, showed behaviors including internal factors as follows: (1) not making preparations for teaching, (2) not showing discipline, (3) lacking mastery of teaching materials. Moreover, the performance of physical education and sports teachers based on external factors shows that physical education and sports teachers: (1) are less motivated to give and receive criticism/suggestions, (2) lack of communication with full intimacy among their teachers, (3) rarely discuss with teachers, (4) lack of support for fellow teachers, (5) lack of feeling that work as a teacher is shared property, (6) lack of control over a conducive atmosphere. And in terms of performance it is suspected that physical education and sports teachers: (1) have not been able to complete tasks quickly and precisely, (2) lack of creative and innovative work, (3) are still waiting for superiors' instructions, (4) provide unsatisfactory services to students.

Therefore, to improve the performance of physical education and sports teachers in accordance with the opinion of Husdarta [5] are as follows: 1) Supervision services; 2) Principal leadership; 3) Learning facilities; 4) Competence; and 5) Motivation absolute achievement to watch out for. Because deep physical education and sports learning operations in schools show there is a contribution to improving teacher performance.

Education in the current era of globalization is expected to produce quality graduates, who have the ability in scientific knowledge and faith [6]. This expectation is as contained in Law No. 20 of 2003 concerning the National Education System in Chapter 1 article 3 as stated in the Indrayogi thesis [7] states that:

National Education functions to develop capabilities and shape the dignified character and civilization of the nation in the context of developing the intellectual life of the nation, aiming at developing the potential of learners to become human beings who believe in and fear God Almighty, have noble, healthy, knowledgeable, capable, creative, independent, and become democratic citizens and responsible (Ministry of National Education, 2005).

Besides having pedagogical abilities, teachers must also have high work motivation, especially motivation in learning activities, have initiative and be creative to build a more pleasant learning atmosphere. Teachers who have high work motivation will produce good performance [8]. Therefore, teachers in improving their work need to be supported by pedagogical competence and high motivation both from within and from outside themselves [9].

Factors that can reduce the performance of a teacher are very complex, including difficulties in making Syllabus, Lesson plan, Evaluation, and Assessment. Various facts and obstacles in the field were found. One of them is the pedagogical competence and motivation of physical education and sports teacher. Differences in pedagogical competence and motivation of physical education teachers are thought to be obstacles to educational progress, including factors such as training and work experience, education, personality attitudes, organizations, leaders, social conditions, individual needs, workplace conditions, abilities, motivation work and so on.

Motivation according to Gunarsa (1978) in Husdarta [5] explains that "Motivation is an impulse or will that causes the emergence of a kind of power for someone to act or act in other words behave". Basically, motivation can be sourced from a person or often known as internal motivation and can also be sourced from outside oneself or also called external motivation [10].

Motivation is abstract psychological energy [11], its form can only be observed in the form of manifestations of the behavior it displays. Motivation as a psychological process is a reflection of the strength of an interaction between cognition, experience, and needs. Alderman (1974) in Husdarta [5] explained: "there is no achievement without motivation". So the achievement or improvement of individual performance is an amalgamation of skills with motivation. Harlow (1965) in Husdarta [5] explains that "Motivation is the fundamental driving thrust that generates behavior". So motivation is an effort to streamline the drive that is the basis of behavior to achieve goals. Teachers are very instrumental in fostering students' motivation, even though the emergence of that motivation by force on them. Gradually his awareness will arise to learn according to his desires. The objectives of this study are to describe the contribution of pedagogical competence and motivation towards the working performance of the teachers of physical education, health, and sports in the Elementary Schools in The District of Kusan Hilir, The Regency of Tanah Bumbu.

\section{Methodology}

This research uses the "Ex Post Facto" method which is a systematic empirical investigation in which the research does not control the variable that has occurred, or because the existence of the variable has occurred, or because the variable basically cannot be manipulated. The conclusion about the 
relationship between these variables is made based on differences that accompany the independent variable and the dependent variable, without direct intervention according to Kerlinger (1973) in Emzir [12].

The researcher tries to determine the cause or reason for the existence of differences in the assessment of individuals. Researchers try to be able to hypothesize that participation in education is a major factor that can contribute.

\section{RESULTS AND DISCUSSION}

Contribution hypothesis is tested in the form of two perceptions: 1) testing the relative contribution hypothesis which only pays attention to the variables studied or ignores other variables on the performance of the Physical Education and Sports Teachers in Primary Schools Kusan Hilir District Tanah Bumbu District, 2): the hypothesis testing contributions effective pay attention to variables other than those studied or pay attention to other variables that the performance of the Physical Education and Physical Education Teachers in the Kusan Hilir District Tanah Bumbu District is not only contributed by the variables studied alone.

Based on the results of the analysis states there is a contribution of pedagogical competence to the performance of the Physical Education and Physical Education Teachers in the Kusan Hilir Subdistrict, Tanah Bumbu District. The results of the analysis concluded that pedagogical competence made a small contribution to the performance of the Physical Education and Physical Education Teachers in the Kusan Hilir Subdistrict, Tanah Bumbu District, specifically a relative contribution of $35.1 \%$ and an effective contribution of $33.4 \%$. This means that there is a contribution of pedagogical competence to the performance of the Physical Education and Physical Education Teachers in the Kusan Hilir District, Tanah Bumbu District.

Based on the results of the analysis states there is a contribution of motivation achievement to the performance of the Physical Education and Physical Education Teachers in the Kusan Hilir Subdistrict, Tanah Bumbu District, that is to say a relative contribution of $42.5 \%$ and an effective contribution of $41.0 \%$. The results of the analysis stated that there was a contribution of pedagogical competence and achievement motivation to the performance of the Physical Education and Physical Education Teachers in the Kusan Hilir Subdistrict, Tanah Bumbu District.

There is a significant contribution to the performance of the Physical Education Teachers in the Kusan Hilir Subdistrict, Tanah Bumbu District. The relative contribution of pedagogical competence and achievement motivation to the performance of the Physical Education and Physical Education Teachers in the Kusan Hilir District Primary School in Tanah Bumbu District is $50.3 \%$ while the effective contribution of pedagogical competence and achievement motivation towards the performance of the Physical Education and Physical Education Teachers in Kusan Hilir District Tanah Bumbu by 47.7\%. Competencies that must be possessed by physical education teachers are professionalism as a basis in physical education learning without ignoring the importance of the other three competencies namely personal, pedagogical and social competencies [13]. Achievement motivation is a very important thing in the learning process at school [14].

\section{CONCLUSION}

The results of this study can be concluded that the performance of Physical Education and Physical Education Teachers in Kusan Hilir Subdistrict, Tanah Bumbu District is a contribution from pedagogical competence and achievement motivation, both of which are elements that support the performance of Physical Education and Physical Education Teachers in Kusan Hilir Subdistrict, Tanah Bumbu District. This means that if the performance of the Physical Education and Physical Education Teachers of the Primary School District of Kusan Hilir, Tanah Bumbu District, the teacher has good pedagogical competence and has a strong achievement motivation also from within a teacher and encouragement from the surrounding environment, to encourage the teacher to have a performance better or increase.

\section{ACKNOWLEDGMENT}

We would like to be grateful to the Dean of Teacher Training and Education Faculty, Lambung Mangkurat University, who has supported us in the form of funding. Therefore we could join this International Conference.

\section{REFERENCES}

[1] N. Omeri, "Pentingnya Pendidikan Karakter Dalam Dunia Pendidikan, Manajer Pendidikan," vol. 9, 2015.

[2] I. Muliawati, Amandemen UUD 1945, Jakarta: PT. Suka Buku, 2014.

[3] E. Ningrum, "Membangun Sinergi Pendidikan Akademik (S1) dan Pendidikan Profesi Guru (PPG)," Jurnal Geografi Gea, vol. 12, 2012.

[4] R. Hasibuan, Peran Guru Terhadap Sistem Pembelajaran Pengetahuan Tentang Peraturan dan Ketentuan Lingkungan Hidup Pada Kehidupan Manusia, Jurnal Ilmiah Advokasi, vol. 7, pp. 64-74, 2019.

[5] H. S. S. Husdarta, Manajemen Pendidikan Jasmani, Bandung: Alfabeta, 2009.

[6] M. R. Asmawi, "Strategi meningkatkan lulusan bermutu di perguruan tinggi," Hubs-Asia, vol. 10, 2010.

[7] Indrayogi, Pengaruh Kompetensi dan Motivasi Berprestasi Terhadap Kinerja Guru Pendidikan Jasmani SMP Negeri Se-Kabupaten Majalengka (Tesis), Majalengka, 2013.

[8] S. Setiyati, "Pengaruh kepemimpinan kepala sekolah, motivasi Kerja, dan budaya sekolah terhadap kinerja guru," Jurnal Pendidikan Teknologi dan Kejuruan, vol. 22, pp. 200-206, 2014.

[9] N. P. Ololube, "Teachers' job satisfaction and motivation for school effectiveness: An assessment," Essays in Education, vol. 18, 2006.

[10] S. Riyadi and A. Mulyapradana, "Pengaruh Motivasi Kerja Terhadap Kinerja Guru Radhatul Atfal di Kota Pekalongan,” Jurnal Litbang Kota Pekalongan, vol. 13, 2017

[11] I. F. Harianto, "Perbandingan motivasi belajar siswa dalam mengikuti pembelajaran pendidikan jasmani, olahraga dan kesehatan antara siswa kelas VII SMP Negeri 1 gondang dengan mts miftahul ulum gondang, kabupaten mojokerto," Jurnal Pendidikan Olahraga dan Kesehatan, vol. 4, 2017.

[12] Emzir, Metodologi PenelitianPendidikan: Kuantitatif dan Kualitatif, Jakarta: PT Raja Grafindo Persada, 2007.

[13] B. Riwu, "Kinerja Guru Pendidikan Jasmani dalam Meningkatkan Prestasi Belajar Siswa pada Pendidikan Jasmani Olahraga dan Kesehatan," In Seminar Nasional Pendidikan Olahraga, vol. 1, pp. 215222, November 2017

[14] R. Fatchurrohman, "Pengaruh motivasi berprestasi terhadap kesiapan belajar, pelaksanaan prakerin dan pencapaian kompetensi mata pelajaran produktif," Innovation of Vocational Technology Education, vol. 7,2011 